\title{
Regulation of TGF- $\alpha$ Expression in Human Keratinocytes: PKC-Dependent and -Independent Pathways
}

\author{
SUSAN B. KLEIN, GARY J. FISHER, TIMOTHY C. JENSEN, JOHN MENDELSOHN, \\ JOHN J. VOORHEES, AND JAMES T. ELDER* \\ Department of Dermatology, University of Michigan Medical School, Ann Arbor, Michigan, \\ 48109-0672 (S.B.K. G.J.F., T.C.J., I.I.V., I.T.E.); Memorial Sloan-Kettering Cancer Center, \\ New York, New York 10021 (J.M.)
}

\begin{abstract}
Transforming growth factor- $\alpha$ (TCF- $\alpha$ ) is an autocrine growth factor for epidermal keratinocytes that can induce its own expression (autoinduction). Because the regulation of this process may be important for the control of epidermal growth, we examined the roles of ECF receptor tyrosine kinase and protein kinase $C$ (PKC) in TGF- $\alpha$ autoinduction in cultured human keratinocytes. Antiphosphotyrosine immunoblot analysis demonstrated that ECF and TGF- $\alpha$ rapidly and markedly stimulated tyrosine phosphorylation of a $170 \mathrm{kDa}$ protein in growth factor-deprived keratinocytes. This protein was identified as the EGF receptor by immunoprecipitation using anti-EGF receptor $m A$ bs. Tyrosine phosphorylation and TGF- $\alpha$ mRNA accumulation in response to EGF and TGF- $\alpha$ were both inhibited by a monoclonal antibody against the EGF receptor and by the EGF receptor tyrosine kinase inhibitor RG50864, demonstrating the involvement of the tyrosine kinase activity of the receptor in TGF- $\alpha$ autoinduction. The monoclonal antibody inhibited keratinocyte growth and TGF- $\alpha$ autoinduction with similar potency $\left(\mathrm{IC}_{50} \sim 0.1 \mu \mathrm{g} / \mathrm{ml}\right)$. TGF- $\alpha$ and the PKC activator tetradecanoyl phorbol 12-myristyl, 13-acetate (TPA) had similar effects on TCF- $\alpha$ steady-state mRNA levels, suggesting that PKC activation might be a downstream mediator of TGF- $\alpha$ autoinduction. However, down-regulation of more than $90 \%$ of keratinocyte PKC activity by bryostatin pretreatment abrogated the induction of TGF- $\alpha$ mRNA in response to TPA without affecting the autoinductive response or EGF-stimulated tyrosine phosphorylation. These results indicate that EGF receptor and PKC stimulate TCF- $\alpha$ gene expression by different pathways, and suggest that PKC is not required for TGF- $\alpha$ autoinduction in this system. Moreover, the fact that EGFstimulated tyrosine phosphorylation and TGF- $\alpha$ autoinduction were not potentiated after PKC down-regulation suggests that PKC does not exert a tonic inhibitory influence on EGF receptor tyrosine kinase activity in normal human keratinocytes. (c) 1992 Wiley-Liss, Inc.
\end{abstract}

The growth factor receptor-associated tyrosine kinases mediate the pleiotypic effects of their ligands, including cell proliferation (Hanks et al., 1988). Transfection studies have demonstrated that the tyrosine kinase activity of the epidermal growth factor (EGF) receptor mediates the pleiotypic response to EGF in fibroblasts and hematopoietic cells (Honegger et al., 1987; Chen et al., 1987; Pierce et al., 1988). However, transforming growth factor- $\alpha$ (TGF- $\alpha$ ), and not EGF, appears to be the cognate EGF receptor ligand produced in an autocrine fashion in a variety of epithelial tissues (Koyama and Podolsky, 1989; Cartlidge and Elder, 1989; Malden et al., 1989; Mead and Fausto, 1989; Markowitz et al., 1990). TGF- $\alpha$ binds to the EGF receptor with high affinity (Massague, 1983; Derynck et al., 1984), and overexpression of TGF $-\alpha$ in transgenic mice results in epithelial hyperplasia in several epithelial tissues (Matsui et al., 1990; Jhappan et al., 1990; Sandgren et al., 1990). TGF- $\alpha$ is markedly overex- pressed in the skin lesions of psoriasis, an inflammatory and hyperplastic skin disease (Gottlieb et al., 1988; Elder et al., 1989a; Higashiyama et al., 1991). Recently, targeted overexpression of TGF- $\alpha$ in murine epidermis has been shown to cause epidermal hyperplasia and scaling similar to that seen in psoriatic lesions (Vassar and Fuchs, 1991). TGF- $\alpha$ and EGF both stimulate TGF- $\alpha$ expression (autoinduction) in murine and human keratinocytes (Coffey et al., 1987, 1988). Since TGF- $\alpha$ is potently mitogenic for keratinocytes (Coffey et al., 1987; Barrandon and Green, 1987; Elder et al., $1989 \mathrm{~b}$ ), increased EGF receptor tyrosine kinase activity could explain both the hyperplasia and the overex-

Received August 29, 1991; accepted November 26, 1991.

*To whom reprint requests/correspondence should be addressed. 
pression of TGF- $\alpha$ which occur in psoriasis. In fact, increased EGF-dependent tyrosine kinase activity has been observed in psoriatic lesions (Gentleman et al., 1984).

One candidate for altered regulation of EGF receptor tyrosine kinase activity in psoriasis is protein kinase $\mathrm{C}$ (PKC). PKC has been reported to inhibit EGF receptor tyrosine kinase activity via phosphorylation of a threonine residue at position 654 of the receptor (Friedman et al., 1984; Davis, 1988; Livneh et al., 1988; Decker et al., 1990). Thus, PKC may normally act as a negative regulator of EGF receptor activation. PKC activity is significantly reduced in psoriatic epidermis (Horn et al., 1987). By this concept, reduced PKC activity in psoriasis would potentiate keratinocyte responses to EGF receptor activation, including proliferation and expression of the EGF receptor agonist, TGF- $\alpha$.

Alternatively, it is also possible that activation, rather than down-regulation, of $\mathrm{PKC}$ is responsible for increased TGF- $\alpha$ expression in psoriasis. Diacylglycerol (DAG) and tetradecanoyl phorbol acetate (TPA), two agents which activate PKC, stimulate keratinocyte production of TGF- $\alpha$ mRNA and protein (Pittelkow et al., 1989). Moreover, several lines of evidence suggest that chronic PKC activation occurs in psoriasis. Phospholipase C (PLC) activity is markedly increased in psoriatic lesions (Bartel et al., 1987; Bergers et al., 1990; Fisher et al., 1990), as is the content of its product, the PKC activator diacylglycerol (Fisher et al., 1990). It has been suggested that down-regulation of PKC in response to chronic activation could explain the reduced PKC levels characteristic of psoriatic epidermis (Fisher et al., 1990).

One possible stimulus for $\mathrm{PKC}$ activation in psoriasis is TGF- $\alpha$ itself. Ligand binding results in tyrosine phosphorylation and activation of phospholipase C-gamma (PLC-gamma) by EGF receptor tyrosine kinase in A431 cells (Wahl et al., 1988; Margolis et al., 1989; Nishibe et al., 1990). Consistent with this model, EGF was found to activate phosphoinositide turnover and stimulate phosphorylation of the PKC-specific substrate p 80 in the immortalized murine keratinocyte line, Balb/MK (Moscat et al., 1988). These results, coupled with the observation that direct activators of PKC are known to stimulate expression of TGF- $\alpha$ (Pittelkow et al., 1989), suggest that PKC might be a distal component of the signal transduction pathway mediating TGF- $\alpha$ autoinduction, and other cellular responses to TGF- $\alpha$ as well.

In order to address these interrelated issues, we have determined whether 'TGF- $\alpha$ autoinduction requires activation of the EGF receptor tyrosine kinase in human keratinocytes, and whether PKC activation is involved in this process as a postreceptor event. In addition, in order to determine whether PKC actually acts as a negative regulator of the EGF receptor tyrosine kinase in intact epidermal cells, we have determined whether experimental reduction in PKC activity can potentiate EGF receptor tyrosine kinase activation and autoinduction of TGF- $\alpha$ in human keratinocytes.

\section{MATERIALS AND METHODS Reagents}

Bryostatin 1 was generously provided by Dr. G. Petit, University of Arizona, and the tyrphostins RG 50864 and 50862 were kindly supplied by Rorer Biotechnology, King of Prussia, PA. Recombinant human TGF- $\alpha$ was provided by Dr. R. Derynck, Genentech, Inc., South San Francisco, CA, or purchased from Collaborative Research. TGF- $\beta 1$ from bovine bone was the kind gift of Dr. L. Ellingsworth, Collagen Corp., Palo Alto, CA. Preparation and characterization of the anti-EGF receptor monoclonal antibody 225 IgG has been described (Kawamoto et al., 1983; Gill et al., 1984; Sunada et al., 1986).

TPA and the monoclonal antibody MOPC 21 were from Sigma, and bovine insulin bovine pituitary extract and murine submaxillary gland epidermal growth factor were from Clonetics. Recombinant human cytokines IL-6 and GM-CSF were purchased from Amgen, IL-2, PDGF, and IFN-gamma from Collaborative Research, and IL-1 $\alpha$ from Dainippon. All other biochemicals were of reagent grade.

\section{Keratinocy te culture}

Cultured adult human keratinocytes were propagated from keratome biopsies of human skin as described (Tsao et al., 1982; Wille et al., 1984), using a commercially available modification of MCDB 153 medium optimized for high density keratinocyte growth (Keratinocyte Growth Medium, Clonetics). Secondary cultures in the second to fourth passage were deprived of polypeptide growth factors at 40 to $50 \%$ confluence by incubation in MCDB 153 or Keratinocyte Basal Medium (Clonetics) for $\mathbf{4 8}$ hours prior to agonist treatment as described (Coffey et al., 1987). During this period, cell confluence increased to 80 to $90 \%$. For analysis of TGF- $\alpha$ mRNA levels, cells were treated with natural murine EGF (Clonetics) or human recombinant TGF- $\alpha$ (Collaborative Research) at various doses for various times as described in the figure legends. Unless otherwise specified, the standard stimulation with either agent was 4 hours of treatment with $20 \mathrm{ng} / \mathrm{ml} \mathrm{EGF}$ or TGF- $\alpha$.

Clonal growth assays were performed as described (Tsao et al., 1982; Wille et al., 1984) except that Keratinocyte Basal Medium (Clonetics) was used instead of MCDB 153 and cells were plated at 2,000 rather than 400 cells per $60 \mathrm{~mm}$ dish.

\section{RNA extraction and analysis}

RNA was isolated by guanidinium isothionate with (Chomczynski and Sacchi, 1987) or without acid phenol extraction as described (Nickoloff et al., 1989). Methods for blot hybridization and washing, probe preparation and labelling, and laser densitometry methods have been described (Elder et al., 1990). Briefly, $20 \mu \mathrm{g}$ total RNA was separated by electrophoresis in $1 \%$ agarose gels, transferred to derivatized nylon membranes (Zeta-Probe, Bio-Rad, Richmond, CA), and hybridized for $18-24$ hours against $1 \times 10^{6} \mathrm{cpm} / \mathrm{ml}$ randomprimed probe in $50 \%$ formamide, $5 \mathrm{X}$ SSC, $50 \mathrm{mM}$ sodium phosphate (pH 7.0), 1X Denhardt's solution, 250 $\mu \mathrm{g} / \mathrm{ml}$ yeast tRNA, $100 \mu \mathrm{g} / \mathrm{ml}$ denatured sonicated salmon sperm DNA, and $1 \%$ SDS. After autoradiography at $-70^{\circ} \mathrm{C}$ using intensifying screens, band intensities were quantitated by laser densitometry using an LKB model 2202 densitometer coupled to a HewletPackard 3390A integrator. Only bands which fell in the 
linear range of densitometric responsiveness, as determined by loading different amounts of input RNA, were used. Unless otherwise indicated, data which have been quantitated by densitometry are normalized to the reference gene, cyclophilin, and expressed as fold-change relative to control untreated samples as described (Elder et al., 1990).

\section{Protein kinase $C$ assay}

Total cellular PKC activity was measured in cultured keratinocytes deprived of growth factors for 30 hours, and bryostatin or DMSO vehicle was added for an additional 18 hours. Cells were harvested by scraping on ice in $20 \mathrm{mM}$ Tris-HCl (pH 7.5), 5 mM EGTA, 2 mM EDTA, $10 \mathrm{mM} \beta$-mercaptoethanol, and $0.01 \%$ leupeptin, and disrupted by sonication. Total cellular PKC was extracted by addition of $1 \%$ Triton X-100 and partially purified by ion exchange chromatography (Kikkawa et al., 1982). Total PKC activity was determined by subtracting the histone phosphorylation obtained in the absence of calcium, phosphatidylserine, and TPA from that obtained in their presence (Fisher et al., 1987).

\section{Western blot assay for tyrosine phosphorylation}

Keratinocytes grown in $100 \mathrm{~mm}$ dishes were depleted of growth factors for 48 hours and treated with various doses of EGF or TGF- $\alpha$ as described above. After various periods of time (usually 5 minutes), cells were lysed for determination of tyrosine phosphorylation essentially as described (Honegger et al., 1990). Cells were rapidly placed on ice and washed once with ice-cold Dulbecco's phosphate buffered saline (PBS) without calcium and magnesium (Gibco) containing $10 \mu \mathrm{M}$ sodium orthovanadate, then scraped into $500 \mu$ lysis buffer containing $50 \mathrm{mM}$ HEPES, $150 \mathrm{mM}$ NaCl, $1 \mathrm{mM}$ EGTA, $1.5 \mathrm{mM} \mathrm{MgCl}_{2}, 10 \%$ glycerol, $1 \%$ Triton X-100, $100 \mathrm{mM} \mathrm{NaF}, 10 \mathrm{mM}$ sodium pyrophosphate, $200 \mu \mathrm{M}$ sodium orthovanadate, $30 \mathrm{mM}$ p-nitrophenyl phosphate, $4 \mathrm{\mu g} / \mathrm{ml}$ phenylmethylsulfonyl fluoride, 10 $\mu \mathrm{g} / \mathrm{ml}$ leupeptin, and $10 \mu \mathrm{g} / \mathrm{ml}$ aprotinin. Lysates were passed three times through a sterile $21 \mathrm{G}$ needle and spun in a microfuge at $4^{\circ} \mathrm{C}$ for 5 minutes. Supernatants were either stored at $-20^{\circ} \mathrm{C}$ for up to one week or analyzed directly. Forty to $100 \mu \mathrm{g}$ protein (as determined by the Bradford dye-binding assay, Bio-Rad, Richmond, CA) were subjected to SDS-PAGE using precast gels (Novex) according to the manufacturer's instructions. Samples were transferred to $0.22 \mu$ nitrocellulose sheets using a semi-dry blotting apparatus (Bio-Rad) according to manufacturer's instructions. Filters were blocked in $5 \%$ nonfat dry milk in PBS containing $0.1 \%$ $\mathrm{NaN}_{3}$ (blotto) for 1 to 4 hours at $20^{\circ} \mathrm{C}$ or overnight at $4^{\circ} \mathrm{C}$, then incubated in the antiphosphotyrosine $\mathrm{mAb}$ PY20 (Oncogene Sciences) at $2 \mu \mathrm{g} / \mathrm{ml}$ in blotto overnight at $4^{\circ} \mathrm{C}$ or for 4 hours at $20^{\circ} \mathrm{C}$. Filters were then washed $3 \times 10$ minutes at $20^{\circ} \mathrm{C}$ in TBS/Tween $(10 \mathrm{mM}$ Tris-HCl (pH 7.4), 0.9\% NaCl, 0.1\% Tween-20), then incubated for 1 hour at $20^{\circ} \mathrm{C}$ in $4 \mu \mathrm{g} / \mathrm{ml}$ rabbit antimouse IgG (Cappell Research Products, Durham, NC) in blotto. After $3 \times 10$ minute washes in TBS/Tween, filters were incubated in ${ }^{125} \mathrm{I}$ staph $\mathrm{A}$ protein $(10 \mu \mathrm{Ci} /$ $\mathrm{ml},>30 \mu \mathrm{Ci} / \mu \mathrm{g}, \mathrm{ICN}$, Costa Mesa, CA) in blotto,
TABLE 1. Ligand specificity of TGF- $\alpha$ induction ${ }^{1}$

\begin{tabular}{lrccc}
\hline Agonist $^{2}$ & $\mathbf{n}$ & Concentration & Induction $^{3}$ & 95\% C.I. ${ }^{4}$ \\
\hline TGF- $\alpha$ & 39 & $20 \mathrm{ng} / \mathrm{ml}$ & 5.0 & $3.7-6.3$ \\
EGF & 19 & $20 \mathrm{ng} / \mathrm{ml}$ & 3.7 & $2.4-5.1$ \\
Insulin & 4 & $5 \mathrm{\mu g} / \mathrm{ml}$ & 1.5 & $0.6-2.4$ \\
IGF-1 & 4 & $50 \mathrm{ng} / \mathrm{ml}$ & 1.5 & $0.3-2.7$ \\
BPE & 4 & $0.4 \%$ & 1.3 & $0.4-2.3$ \\
TGF- $\beta$ & 4 & $2.5 \mathrm{ng} / \mathrm{ml}$ & 1.1 & $0.4-1.8$ \\
IL-6 & 4 & $20 \mathrm{ng} / \mathrm{ml}$ & 1.4 & $0.6-2.2$ \\
GM-CSF & 4 & $20 \mathrm{ng} / \mathrm{ml}$ & 1.3 & $0.6-2.0$ \\
PDGF & 4 & $5 \mathrm{U} / \mathrm{ml}$ & 0.7 & $0.2-1.2$ \\
bFGF & 3 & $2 \mathrm{ng} / \mathrm{ml}$ & 1.1 & $0.4-1.8$ \\
IL-1 $\alpha$ & 3 & $100 \mathrm{U} / \mathrm{ml}$ & 0.7 & $0.4-1.1$ \\
IL-2 & 2 & $100 \mathrm{U} / \mathrm{ml}$ & 0.6 & $<0-1.6$ \\
IFN-gamma & 2 & $100 \mathrm{U} / \mathrm{ml}$ & 0.5 & $<0-1.3$ \\
\hline
\end{tabular}

${ }^{1} Q$ Quiescent keratinocytes were treated for 4 hours with the indicated concentrations of the agonists shown.

2Abbreviations: bFGF, basic fibroblast growth factor; BPE, bovine pituitary extract: GM-CSF, colony stimulating factor (granulocyte-macrophage); IFN-gamma, inter feron-gamma; IGF-1, insulinlike growth factor-1; IJ-1 $\alpha$, interleukin 1-alpha; IL-2, interleukin-2; IL-6, interleukin 6; PDGF, platelet-derived growth factor; TGF- $\beta$, transforming growth factor- $\beta$.

${ }^{3}$ Mean fold-induction relative to untreated quiescent keratinocytes, after normalization to cyclophilin.

${ }^{4} 95 \%$ confidence interval. $95 \%$ confidence intervals were calculated from the standard errors of the induction values.

washed $3 \times 10$ minutes in blotto, dried briefly, and autoradiographed using intensifying screens.

\section{Immunoprecipitation}

Keratinocytes in $100 \mathrm{~mm}$ dishes were treated with EGF (200 ng/ml) for 5 minutes, washed with ice-cold $\mathrm{Ca}^{+}{ }^{+}, \mathrm{Mg}^{++}$-free PBS containing $10 \mu \mathrm{M} \mathrm{NaVO}_{4}$, and lysed in $500 \mu$ ice-cold RIPA buffer as described (Sunada et al., 1990). Immunoprecipitation was carried out by adding $2 \mu \mathrm{g}$ of the anti-EGF receptor mAbs 528 , 225 (Sunada et al., 1986) or 05-101 (UBI) to $250 \mu \mathrm{l}$ of RIPA lysate for 30 minutes at room temperature followed by $5 \mu \mathrm{g}$ of rabbit anti-mouse (RAM) IgG (Cappel) for 15 minutes. $50 \mu \mathrm{l}$ of $10 \%$ Pansorbin was then added, and incubation continued an additional 30 minutes. After pelleting in a microfuge, the pellet was washed twice in $10 \mathrm{mM}$ Hepes $(\mathrm{pH} 7.4), 0.5 \%$ Triton $\mathrm{X}-100,5 \%$ glycerol as described (Sunada et al,, 1990). Electrophoresis, blotting, and decoration with PY20 were as described above, except that the incubation with RAM IgG secondary antibody was omitted.

\section{RESULTS}

We assessed the specificity of TGF- $\alpha$ mRNA induction in response to various polypeptides to investigate the involvement of the EGF receptor in the process of TGF- $\alpha$ autoinduction. Growth factor-deprived keratinocytes were stimulated for 4 hours with a variety of growth factors and cytokines and induction of TGF- $\alpha$ transcripts was assessed by RNA blot hybridization. Of the 13 factors tested, only TGF $-\alpha$ and EGF significantly induced TGF- $\alpha$ mRNA (Table 1). This ligand specificity strongly suggests that TGF- $\alpha$ autoinduction is mediated by the EGF receptor. In order to further substantiate this conclusion, we measured the effects of $225 \mathrm{IgG}$, a well-characterized anti-EGF receptor monoclonal antibody (Kawamoto et al., 1983; Gill et al., 1984; Sunada et al., 1986), on TGF- $\alpha$ autoinduction and EGF receptor tyrosine phosphorylation in keratinocytes. At $4^{\circ} \mathrm{C}, 225$ IgG competitively inhibits EGF and TGF- $\alpha$ binding, 


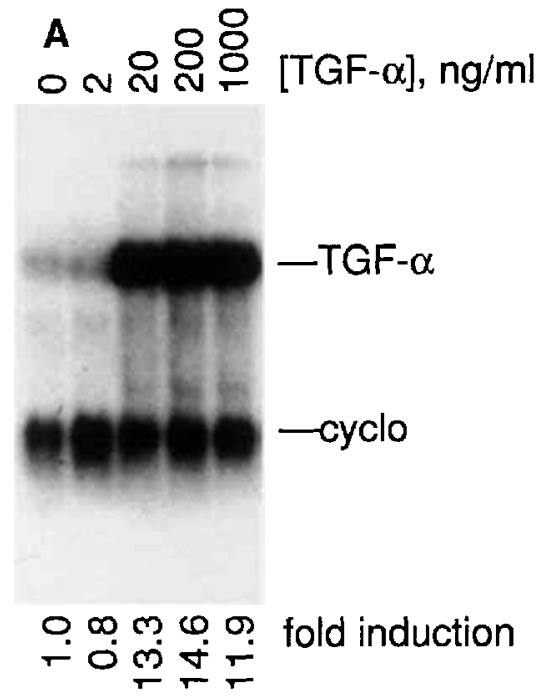

Fig. 1. Inhibition of TGF- $\alpha$ autoinduction by $\mathrm{mAb} 225 \mathrm{IgG}$. A: Dose response of TGF- $\alpha$ autoinduction. Growth factor-depleted keratinocytes were incubated with the indicated concentrations of TGF- $\alpha$ for 4 hours, followed by lysis and RNA blot analysis against TGF- $\alpha$ and cyclophilin probes. Fold-induction of TGF- $\alpha$ mRNA after normalization to cyclophilin is shown below the autoradiogram. B: Autoinduction of TGF- $\alpha$ mRNA is inhibited by mAb 225 IgG. Growth factordepleted keratinocytes were incubated with the indicated concentrations of $\mathrm{mAb} 225 \mathrm{IgG}$ for 30 minutes, followed by addition of TPA (20 nM), TGF- $\alpha$ (20 ng/ml) or EGF (20 ng/ml). RNA was harvested after 4 hours and analyzed by blot hybridization. Data are expressed as a percentage of the stimulation over baseline obtained for each agonist in the absence of $225 \mathrm{IgG}$. Data shown represent mean \pm SEM of three or more determinations. C: RNA blot hybridization of a representative experiment. $C$ indicates no addition of agonist.

while at $37^{\circ} \mathrm{C}$, it causes EGFR internalization in intact cells but does not stimulate EGFR autophosphorylation (Sunada et al., 1986).

Figure 1A demonstrates the dose response of TGF- $\alpha$ mRNA accumulation in response to exogenous TGF- $\alpha$ in cultured keratinocytes (autoinduction). This response has previously been shown to correlate with the accumulation of TGF- $\alpha$ protein in the culture supernatant under these conditions (Coffey et al., 1987). Maximal induction was obtained at a dose of $20 \mathrm{ng} / \mathrm{ml}$ TGF- $\alpha$, and this dose was used for subsequent experiments. Pretreatment with 225 IgG for 30 minutes potently and markedly inhibited TGF- $\alpha$ mRNA accumulation in response to both TGF- $\alpha$ and EGF. In contrast, the antibody did not inhibit accumulation of TGF- $\alpha$ mRNA accumulation in response to TPA (Fig. 1B,C).

As shown in Figure 2A, EGF and TGF- $\alpha$ rapidly stimulated tyrosine phosphorylation of a band of $\mathrm{Mr} \sim 170 \mathrm{kDa}$ in growth factor-depleted human keratinocytes. Persistent phosphorylation of this band was noted in the continued presence of TGF- $\alpha$ agonist for up to 4 hours. The $170 \mathrm{kDa}$ band was demonstrated to be the EGF receptor by co-migration with a band present in EGF-stimulated A431 control membranes (Fig. 2AC), and by immunoprecipitation of a band of $170 \mathrm{kDa}$ with three different anti-EGF receptor mAbs (Fig. 2B). As shown in Figure 2C, EGF-stimulated tyrosine phosphorylation of the $170 \mathrm{kDa}$ band was completely inhibited by 30 minutes preincubation with $5 \mu \mathrm{g} / \mathrm{ml}$ of the
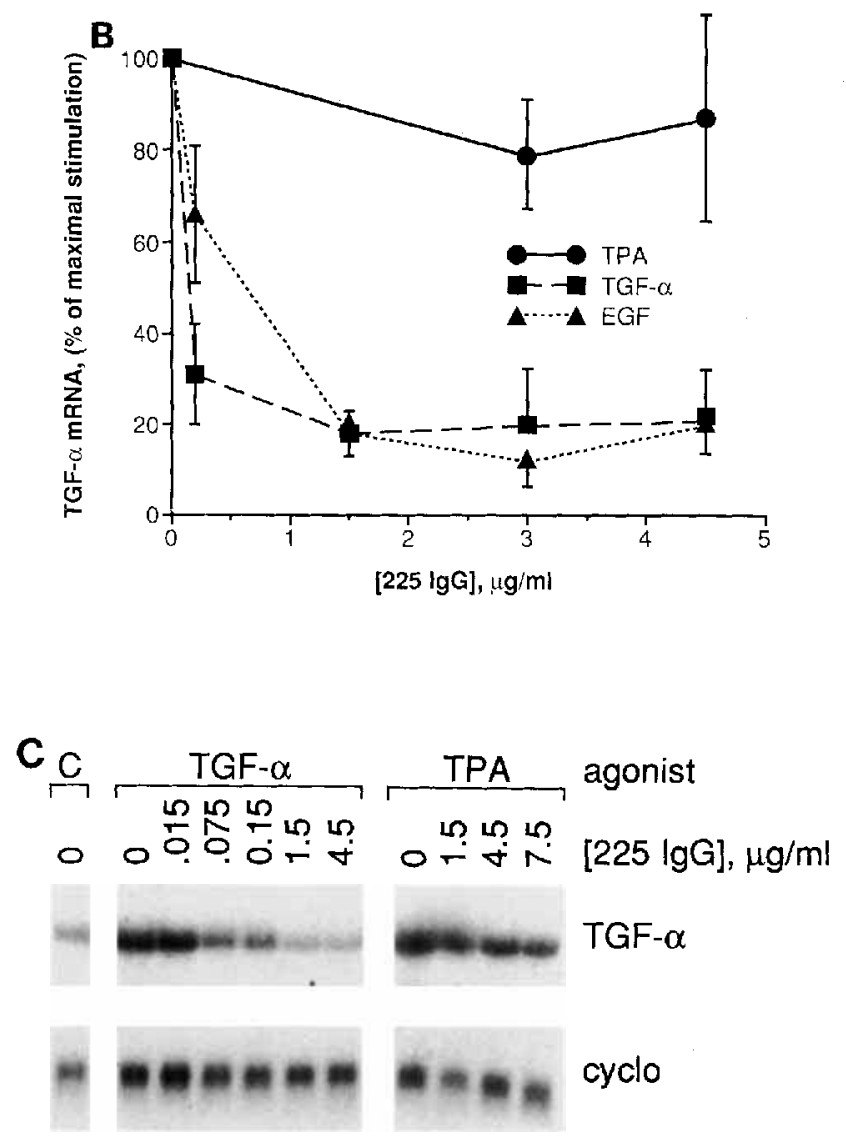

anti-EGF receptor $\mathrm{mAb} 225 \mathrm{IgG}$, while the presence of the same concentration of the isotype control $\mathrm{mAb}$ MOPC 21 had no effect. As previously reported in A431 cells (Sunada et al., 1986), treatment of keratinocytes with $225 \mathrm{IgG}$ alone did not result in tyrosine phosphorylation of the $170 \mathrm{kDa}$ band (Fig. 2B).

As shown in Figure 3, mAb 225 IgG also inhibited clonal keratinocyte growth with a potency similar to its effects on autoinduction ( $\mathrm{IC}_{50}$ approximately $0.1 \mu \mathrm{g} /$ $\mathrm{ml}$ ). The isotype control antibody, MOPC 21 , was inactive in inhibiting clonal keratinocyte growth (data not shown).

To directly demonstrate a requirement for the tyrosine kinase activity of the EGF receptor in keratinocyte TGF- $\alpha$ autoinduction, we treated growth factordepleted keratinocytes with the tyrphostin RG50864, a specific inhibitor of EGF receptor tyrosine kinase activity (Lyall et al., 1989; Posner et al., 1989). As shown in Figure 4A, RG50864 inhibited EGF- and TGF- $\alpha$-stimulated tyrosine phosphorylation in growth factor-depleted keratinocytes at 40 and $120 \mu \mathrm{M}$. The related tyrphostin, RG50862 (Lyall et al., 1989) was less active, inhibiting tyrosine phosphorylation at $120 \mu \mathrm{M}$ but not at $40 \mu \mathrm{M}$. In some experiments, RG50864 alone demonstrated a partial agonist effect (Fig. 4A, left panel). As shown in Figure 4B and C, RG50864 displayed a dosedependent inhibition of TGF- $\alpha$ mRNA accumulation in response to increasing amounts of exogenous TGF- $\alpha$. Relatively high concentrations of RG50864 $(>40 \mu \mathrm{M})$ 

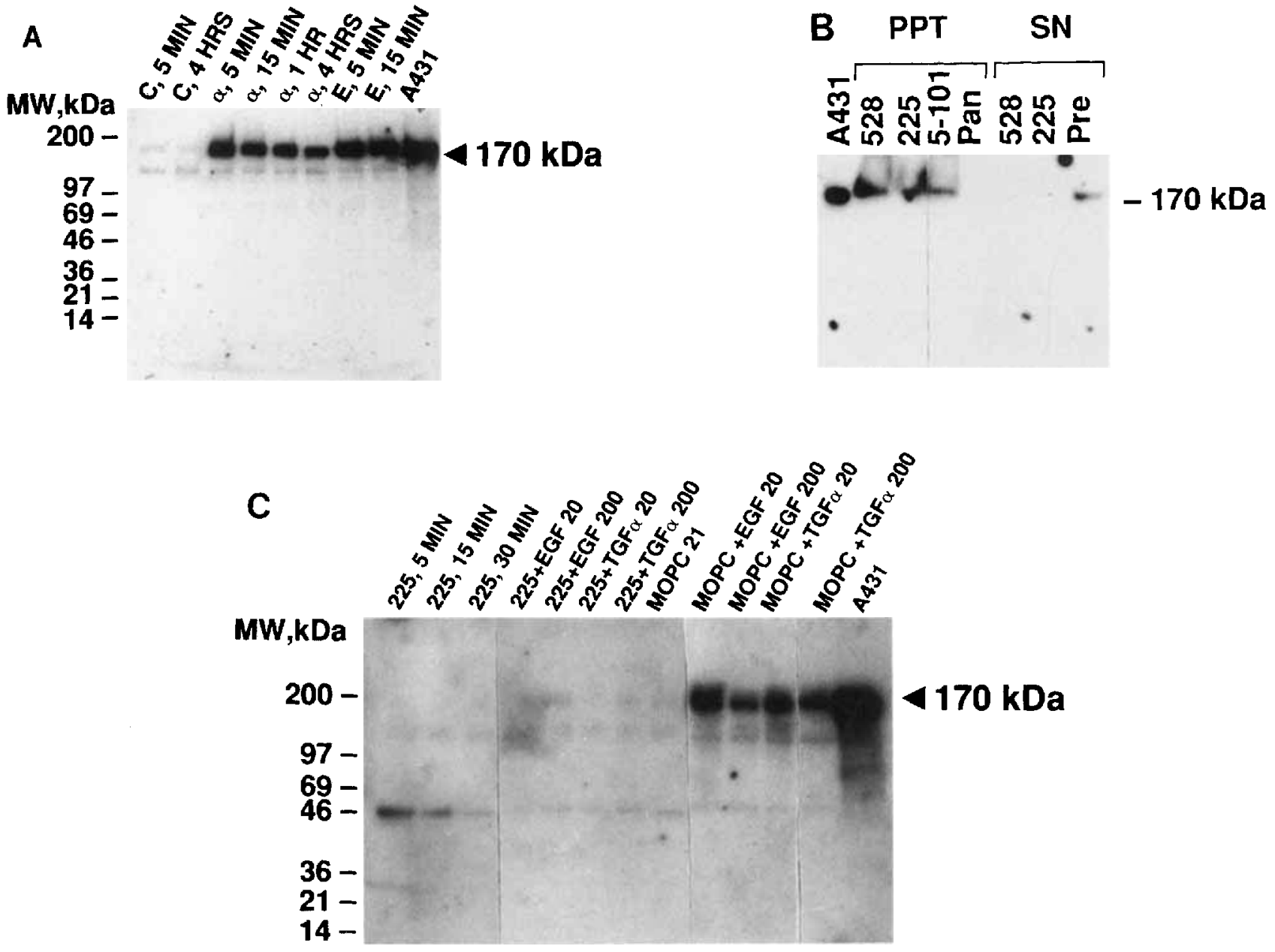

Fig. 2. Immunoblot analysis of tyrosine phosphorylation in intact human keratinocytes. A: Time course of EGF- and TGF- $\alpha-$ stimulated tyrosine phosphorylation. Growth factor-depleted keratinocytes were treated with EGF or TGF- $\alpha$ for the times indicated, then lysed as described in Materials and Methods. Gradient gels of 8-16\% SDSPAGE were loaded with $40 \mu \mathrm{g}$ keratinocyte lysate protein per lane (approximately $2 \times 10^{5}$ cell equivalents), immunoblotted, and decorated with PY20 antiphosphotyrosine mAb as described in Materials and Methods. Mobilities of molecular weight standards are indicated to the left. $\alpha, \mathrm{TGF} \alpha, 20 \mathrm{ng} / \mathrm{ml} ; \mathrm{E}, \mathrm{EGF}, 20 \mathrm{ng} / \mathrm{ml} ; \mathrm{A} 431,5 \mu \mathrm{l}$ solubilized membrane preparation from $5 \times 10^{4} \mathrm{EGF}$-treated $A 431$ cells (UBI). B: Immunoprecipitation of EGF receptors. EGF-treated keratinocytes were lysed in RIPA buffer and equal aliquots were immunoprecipitated (PPT) using the anti-EGFR mAbs 528, 225, or 5-101 as

were required to inhibit both tyrosine phosphorylation and TGF- $\alpha$ autoinduction in keratinocytes (see Discussion).

Because agents which activate $\mathrm{PKC}$ can stimulate TGF- $\alpha$ expression (Pittelkow et al., 1989), and because of numerous studies suggesting a link between EGF receptor activation, phospholipase $\mathrm{C}$ activation, and increased levels of the potential PKC activators calcium and diacylglycerol (see introduction and Discussion), we wished to determine whether PKC activation was a downstream signal transduction event required for TGF- $\alpha$ autoinduction. If $\mathrm{PKC}$ is not a downstream mediator of this process, then it process should not be affected by experimental reduction of $\mathrm{PKC}$ activity described in Materials and Methods. Primary antibody was omitted in the pansorbin control (Pan). Equal aliquots $(10 \mu \mathrm{l} / 100 \mu \mathrm{l})$ of the solubilized immunoprecipitates were analyzed by SDS-PAGE followed by immunoblotting against PY20 as described above. Equal aliquots (20 $\mu \mathrm{l} / 250 \mu \mathrm{l}$ ) of the 528 and 225 post-immunoprecipitation supernatants (SN) and pre-immunoprecipitation lysate (Pre) were run in parallel. A431, EGF-stimulated A431 membranes. C: Inhibition of EGF- and TGF- $\alpha$-stimulated tyrosine phosphorylation by mAb 225 IgG. Growth factor-depleted keratinocytes were treated with $5 \mu \mathrm{g} / \mathrm{ml} 225 \mathrm{lgG}$ for 30 minutes, then treated for 5 minutes with the indicated concentra-

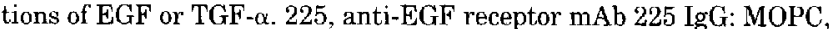
isotype control mAb MOPC 21. Concentrations of EGF and TGF- $\alpha$ are given in ng/ml. A431, EGF-stimulated A431 membranes.

prior to TGF- $\alpha /$ EGF treatment. Because of the lack of specificity of most protein kinase inhibitors, we chose to assess the PKC independence of TGF- $\alpha$ autoinduction by down-regulation of PKC activity (Tapley and Murray, 1984). TPA is commonly used for this purpose, but is unsuitable for use in keratinocytes because it causes loss of EGF receptors in these cells (Jeng et al., 1985; Jetten et al., 1989) and causes a sustained induction of TGF- $\alpha$ mRNA (Pittelkow et al., 1989). Bryostatin is a macrocyclic lactone which causes membrane translocation of PKC followed by down-regulation of PKC activity (Kraft et al., 1987), with only a transient loss of EGF binding in keratinocytes (Sako et al., 1987; Jetten et al., 1989). To verify that $\mathrm{PKC}$ activity was reduced by 


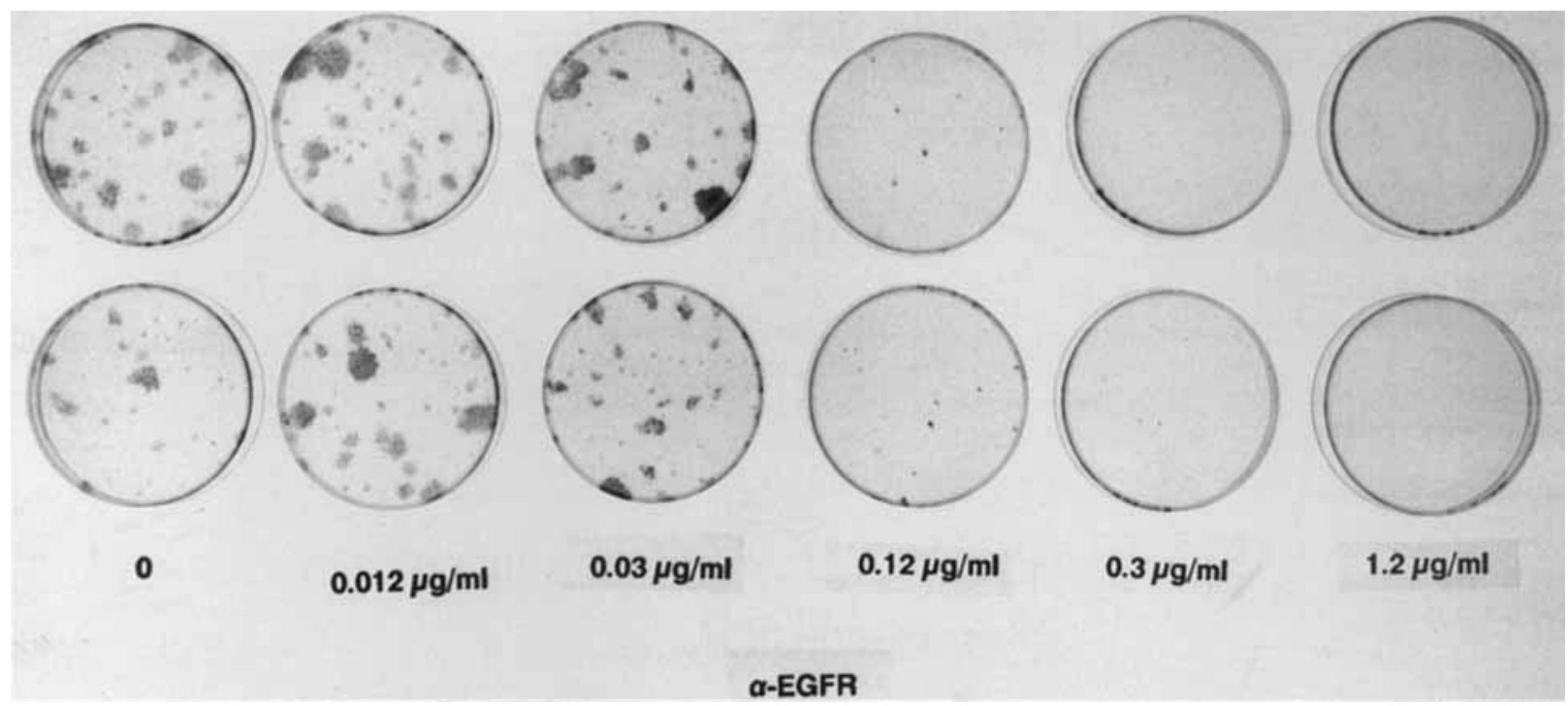

Fig. 3. Inhibition of keratinocyte growth by anti-EGFR IgG. Keratinocytes were plated in Keratinocyte Basal Medium (Clonetics) containing EGF (1 $\mathrm{ng} / \mathrm{ml})$, insulin $(5 \mu \mathrm{g} / \mathrm{ml})$, and bovine pituitary extract $10.4 \%$ ). Twenty-four hours after plating, azide-free $225 \mathrm{IgG}$ in phosphate buffered saline was added to each dish at the indicated concentrations. Duplicate dishes were fixed and stained with crystal violet two weeks later.

bryostatin, growth factor-depleted keratinocytes were treated with various concentrations of bryostatin for 18 hours and PKC activity was determined. After $20 \mathrm{nM}$ bryostatin treatment, PKC activity was reduced by an average of $91 \%$ (Fig. 5). Consistent with its inhibitory effect on PKC activity, at this dose bryostatin totally inhibited TPA-stimulated accumulation of TGF- $\alpha$ mRNA (Fig. 6A). Furthermore, bryostatin, unlike TPA, did not itself induce TGF- $\alpha$ mRNA (Fig. 6A). Consistent with the hypothesis that PKC activation is not a downstream mediator of TGF- $\alpha$ autoinduction, accumulation of TGF- $\alpha$ mRNA in response to exogenous TGF- $\alpha$ was not inhibited by bryostatin treatment (Fig. 6B,C).

Because $\mathrm{PKC}$ has been reported to inhibit $\mathrm{EGF}$ receptor tyrosine kinase activity (see introduction), we hypothesized that reduction of $\mathrm{PKC}$ activity by bryostatin would potentiate EGF receptor activation in response to ligand as well as TGF- $\alpha$ autoinduction. However, as shown in Figure $6 \mathrm{~B}$ and $\mathrm{C}$, pretreatment with 2 or 20 nM bryostatin for 18 hours did not alter the dose dependence or increase the magnitude of the induction of TGF- $\alpha$ mRNA in response to exogenous TGF- $\alpha$. In addition, pretreatment with $20 \mathrm{nM}$ bryostatin failed to potentiate tyrosine phosphorylation of the $170 \mathrm{kDa}$ band on Western blots in response to 20 or $200 \mathrm{ng} / \mathrm{ml} \mathrm{EGF}$ (Fig. 7).

\section{DISCUSSION}

Several studies involving transfection of normal and mutant receptors have demonstrated an important role for the tyrosine kinase activity of the EGF receptor in mediating the pleiotypic response to EGF (Honegger et al., 1987; Chen et al., 1987; Pierce et al., 1988). We have hypothesized that one component of this response, the autoinduction of TGF- $\alpha$ mRNA and protein, could be relevant to the pathogenesis of psoriasis (Elder et al., $1989 \mathrm{a}$, and vide supra). However, transfection of EGF receptors cannot be used to assess the role of EGF receptor tyrosine kinase activation in this process in keratinocytes due to endogenous $\mathrm{EGF}$ receptor expression in these cells. Therefore, we have tested the specificity of this response for various polypeptide ligands, and made use of specific antibodies and inhibitors to demonstrate that accumulation of $\mathrm{TGF}-\alpha$ mRNA in response to exogenous TGF- $\alpha$ or EGF occurs via the EGF receptor and requires its tyrosine kinase activity. In addition, we demonstrate for the first time the pattern of EGF- and TGF- $\alpha$-stimulated tyrosine phosphorylation in intact human keratinocytes, and compare this immediate (proximal) response to agonist to the delayed (distal) response of TGF- $\alpha$ autoinduction under various conditions.

\section{EGF and TGF- $\alpha$ stimulate tyrosine} phosphorylation of a $170 \mathrm{kDa}$ substrate in intact keratinocytes

Figure 2 demonstrates that both EGF and TGF- $\alpha$ rapidly and markedly stimulate tyrosine phosphorylation of a $170 \mathrm{kDa}$ band in detergent lysates of quiescent cultured keratinocytes, consistent with phosphorylation of the EGF receptor. Three different anti-EGFR mAbs immunoprecipitated a band of the same $\mathrm{Mr}$, identifying this band as the EGF receptor (Fig. 2B). Background bands of $40,47,84$, and about $110 \mathrm{kDa}$ have been variably noted in a number of experiments (Figs. $1,4,7)$; however, the molecular identity of these bands is presently unclear. Utilizing metabolic labelling coupled with immunoprecipitation, Dvir and colleagues (1991) have reported EGF-dependent tyrosine phosphorylation of the EGF receptor as well as additional bands in permeabilized keratinocytes grown on fibroblast feeder layers. However, this is the first description of the pattern of EGF- and TGF- $\alpha$-stimulated tyrosine phosphorylation in intact normal keratinocytes. 


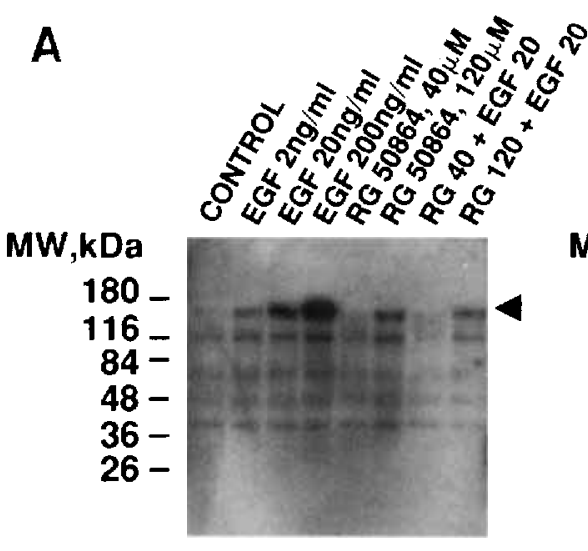

EXPERIMENT 1

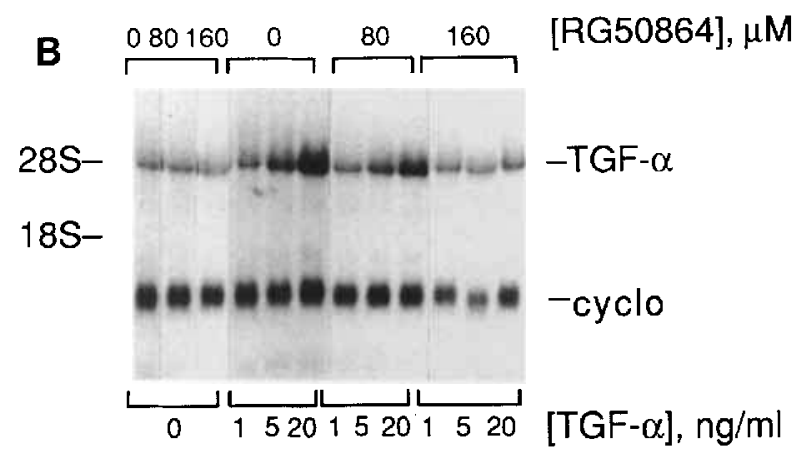

Fig. 4. Inhibition of EGF-stimulated tyrosine phosphorylation and TGF- $\alpha$ autoinduction by tyrphostin. A: Immunoblot analysis of tyrosine phosphorylation. Growth factor-depleted keratinocytes were treated with the indicated concentrations of RG50864 or RG50862 for 18 hours. EGF was then added for 5 minutes at $37^{\circ} \mathrm{C}$, and cells were lysed for immunoblot analysis as described in Materials and Methods. Identical results have been obtained using TGF- $\alpha$ rather than EGF as agonist (not shown). Results shown are representative of 4 independent experiments. B: RNA blot analysis. Quiescent keratinocytes

In most of our experiments, only a single $170 \mathrm{kDa}$ band demonstrated agonist-dependent tyrosine phosphorylation (Figs. 2, 4). However, we have occasionally observed agonist-dependent phosphorylation of a band of about $110 \mathrm{kDa}$, the identity of which is presently unknown (Fig. 7). It is possible that differences in culture conditions and/or the use of permeabilized rather than intact living cells may account for the differences between these our studies and those of Dvir et al. However, in neither study was tyrosine phosphorylation of a Mr $145 \mathrm{kD}$ a band observed, as would be expected if PLC-gamma1 were a predominant substrate for the EGF receptor. Tyrosine phosphorylation of a variety of proteins, including but not limited to growth factor receptors, has been shown to stimulate binding to other proteins bearing Src homology (SH) domains (Koch et al., 1991). Our observation that the $170 \mathrm{kDa}$ band is the predominant protein phosphorylated on tyrosine in response to EGF or TGF- $\alpha$ in intact cells suggests that

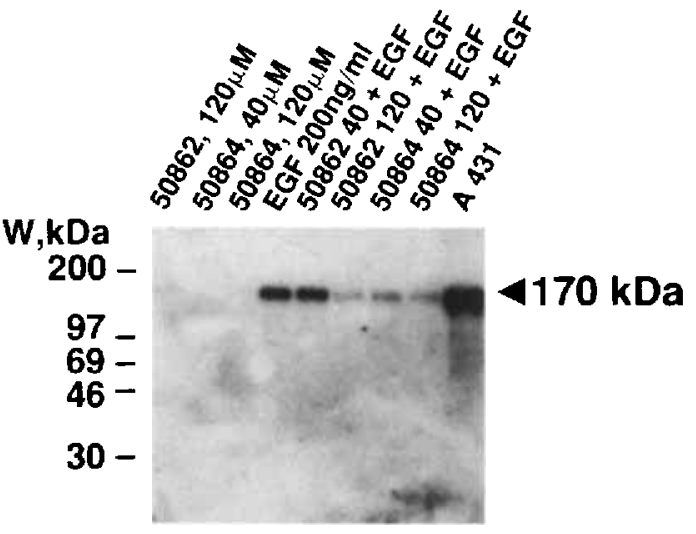

EXPERIMENT 2

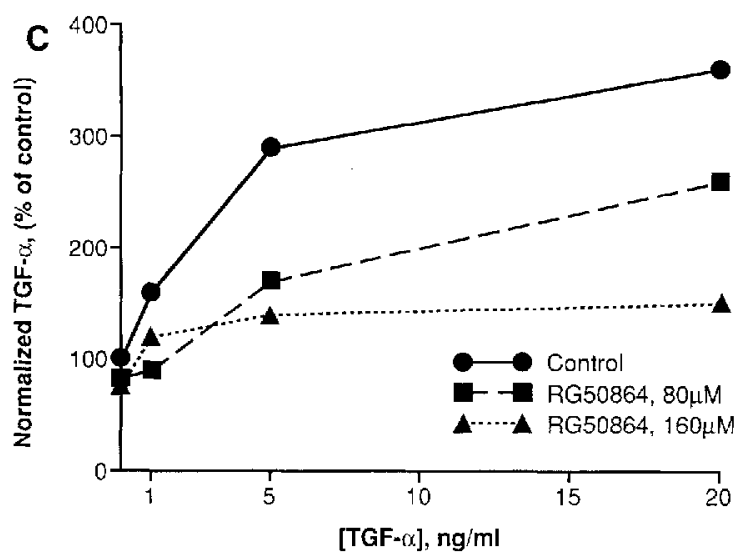

were pretreated for 18 hours with 80 or $160 \mu \mathrm{M}$ RG50864 prior to addition of the indicated amounts of TGF- $\alpha$ for 4 hours. RNA isolation and blot hybridization analysis were as in Fig. $1 \mathrm{~A}$. This autoradiograph is representative of 6 experiments with pretreatment times varying between 2 and 18 hours. C: Quantitation of data shown in Fig. 4B (see Materials and Methods). Data are expressed as a percentage of the TGF- $\alpha$ hybridization obtained without TGF- $\alpha$ or tyrphostin treatment. Values shown are normalized to cyclophilin.

tyrosine phosphorylation of substrates other than the EGF receptor itself may not be central to the mode of EGF/TGF- $\alpha$ action in keratinocytes.

\section{TGF- $\alpha$ autoinduction requires EGF receptor activation}

Of 13 polypeptide ligands tested, only EGF and TGF- $\alpha$ stimulated TGF- $\alpha$ mRNA levels in quiescent keratinocytes (Table 1), which strongly suggests that TGF- $\alpha$ autoinduction is a specific receptor-mediated event. Consistent with this interpretation, autoinduction of TGF $-\alpha$ mRNA (Fig. 1B,C), EGF-dependent tyrosine phosphorylation (Fig. 2C), and keratinocyte growth (Fig. 3) were all markedly inhibited by the antiEGF receptor monoclonal antibody, 225 IgG. The tyrphostin RG50864 markedly inhibited EGF- and TGF$\alpha$-dependent tyrosine phosphorylation (Fig. 4A) and autoinduction of TGF- $\alpha$ mRNA (Fig. 4B,C), strongly suggesting that the tyrosine kinase activity of the EGF 


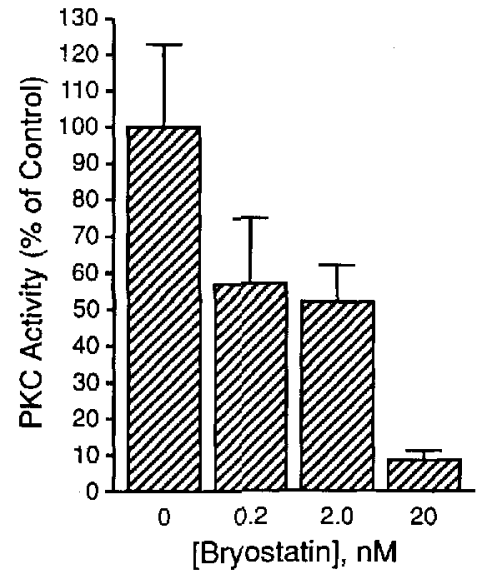

Fig. 5. Down regulation of PKC by bryostatin. Growth factor-depleted keratinocytes were treated with bryostatin and $\mathrm{PKC}$ activity was determined as described in Materials and Methods. Bars indicate mean \pm SEM of 5 experiments (except $0.2 \mathrm{nM}$ bryostatin, 4 experiments). Data are expressed as a percentage of untreated controls.

receptor is required for this process. The dose response of 'TGF- $\alpha$ mRNA accumulation (Fig. 1A) was maximal at $20 \mathrm{ng} / \mathrm{ml} \mathrm{TGF- \alpha} \mathrm{(4} \mathrm{nM}$ ) and ranged from $1-20 \mathrm{ng} / \mathrm{ml}$ $(0.2-4 \mathrm{nM})$, in general agreement with the saturation binding curve for $\mathrm{EGF}$ in human $\mathrm{KC}\left(\mathrm{K}_{\mathrm{d}}=0.5 \mathrm{nM}\right.$, saturation at $2 \mathrm{nM}$ ) (Nickoloff and Mitra, 1989). These results suggest that high receptor occupancy is required for autoinduction under these conditions. The relatively high concentrations of RG50864 required to inhibit autoinduction and tyrosine phosphorylation in these experiments (Fig. 4) could reflect this requirement for high receptor occupancy, and/or the observation that tyrphostin potency is reduced in late log phase/early stationary phase human keratinocytes (Ferriola et al., 1991).

\section{Two pathways for induction of TGF- $\alpha$ mRNA}

Although direct activators of PKC such as TPA and diacylglycerols can clearly cause accumulation of TGF- $\alpha$ mRNA (Pittelkow et al., 1989), several lines of evidence indicate that EGF receptor tyrosine kinase and PKC activation stimulate TGF- $\alpha$ expression by distinct mechanisms. Thus, TGF- $\alpha$ autoinduction was inhibited by the tyrosine kinase inhibitor RG50864 (Fig. 4) but not after down-regulation of over $90 \%$ of keratinocyte PKC activity in response to bryostatin (Figs. 5, 6). In contrast, induction of TGF- $\alpha$ in response to TPA treatment was markedly inhibited by bryostatin (Fig. $6 \mathrm{~B}$ ). It is noteworthy that unlike TPA, bryostatin did not stimulate TGF- $\alpha$ mRNA levels (Fig. $6 \mathrm{~B}$ ). This observation is consistent with several reports demonstrating that bryostatins mimic only some but antagonize many of the actions of TPA (Smith et al., 1985; Sako et al., 1987; Kraft et al., 1987; Jetten et al., 1989; Gschwendt et al., 1988).

\section{TGF- $\alpha$ autoinduction may not require PKC activation}

Based on the insensitivity of TGF- $\alpha$ autoinduction to bryostatin treatment (Fig. 6), we conclude that activa- tion of PKC is not necessary for TGF- $\alpha$ autoinduction in keratinocytes. The use of other protein kinase inhibitors, such as the isoquinolinesulfonamide $\mathrm{H}-7$, is inappropriate for this purpose, since these inhibitors are not specific for inhibition of protein kinase C (Hidaka et al., 1984). Our results are consistent with several reports demonstrating that EGF does not functionally activate PKC in epithelial cells (Vaartjes et al., 1986; Baliga and Morowitz, 1988; Thompson et al., 1988). While modest elevations of phosphoinositide turnover and/or DAG mass have been observed in response to EGF in murine keratinocytes, hamster fibroblasts, A431 cells, and rat hepatocytes (Moscat et al., 1988; Johnson and Garrison, 1987; Kato et al., 1988; Pessin et al., 1990), activation of $\mathrm{PKC}$ in response to $\mathrm{EGF}$ has not been detected by direct measurement. In one study (Moscat et al., 1988), a modest (<twofold) increase in phosphorylation of an acidic $80 \mathrm{kDa}$ protein (MARCKS protein), thought to be a specific substrate for PKC phosphorylation (Blackshear et al., 1985), was observed in response to $\mathrm{EGF}$ in BALB/MK immortalized murine keratinocytes. However, in many cell lines, serum and/or direct $\mathrm{PKC}$ activators such as TPA lead to much larger increases in MARCKS phosphorylation (Blackshear et al., 1991). Moreover, we have been unable to demonstrate significant EGF- or TGF- $\alpha$-stimulated phosphorylation of MARCKS protein in normal human keratinocytes under conditions in which large increases in tyrosine phosphorylation of the $170 \mathrm{kDa}$ protein have been consistently detected (N. Reynolds, T. Jensen, J. Elder, and G. Fisher, manuscript in preparation). Similarly, exhaustive studies of insulin responses in cells massively overexpressing insulin receptors have failed to convincingly demonstrate $\mathrm{PKC}$ activation as a downstream event in the cellular response to insulin (Blackshear et al., 1991). Nevertheless, it remains possible that $\mathrm{PKC}$ isoforms whose activity might not be detectable under our assay conditions and which may not be down-regulated by bryostatin could be involved in the transduction of the autoinductive response to TGF- $\alpha$.

\section{Bryostatin down-regulates PKC but does not potentiate $E G F$ responses}

Phosphorylation of ${ }^{654} \mathrm{Thr}$ of the EGF receptor by PKC results in inhibition of EGFR-TK activity, and mutation of this residue leads to loss of phorbol ester inhibition of EGF-stimulated growth (Friedman et al., 1984; Livneh et al., 1988; Decker et al., 1990). Loss of PKC-mediated inhibition of EGFR-TK could explain the increased TGF- $\alpha$ gene expression and proliferation which occur in the context of reduced PKC activity in psoriatic epidermis. However, we were unable to demonstrate potentiation of $\mathrm{TGF}-\alpha$ autoinduction (Fig. $6 \mathrm{~B}, \mathrm{C})$ or of EGF-stimulated tyrosine phosphorylation (Fig. 7) after down-regulation of PKC activity with bryostatin. These results, as well as the inability of bryostatin to stimulate TGF- $\alpha$ mRNA (Fig. $6 \mathrm{~A}$ ) raise the possibility that $\mathrm{PKC}$ isoforms not detectable by our assay conditions and/or unresponsive to bryostatin are involved in down-regulation of EGF receptor tyrosine kinase activity in keratinocytes. 


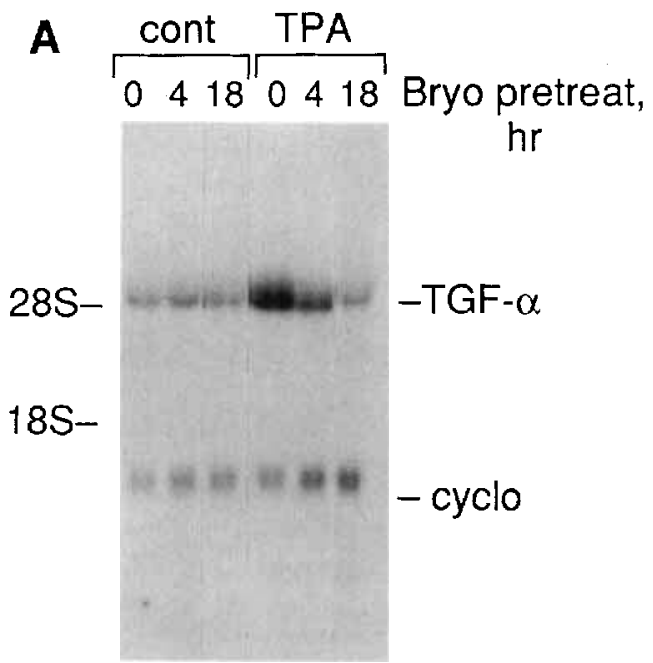

Fig. 6. A: Bryostatin inhibits the accumulation of TGF- $\alpha$ mRNA by TPA. Growth factor-depleted keratinocytes were pretreated with 20 nM bryostatin for either 4 or 18 hours. TPA ( $20 \mathrm{nM}$ ) or DMSO solvent (cont) was then added and RNA was harvested 4 hours later. Therefore, total time of bryostatin treatment was either 8 or 22 hours. There was also no effect of bryostatin alone on TGF- $\alpha$ mRNA levels after 4 hours of treatment (data not shown). TGF- $\alpha$ and cyclophilin transcripts were analyzed by blot hybridization. Mobilities of ribosomal RNAs are indicated to the left. B: TGF- $\alpha$ autoinduction is unaffected by bryostatin. Growth factor-depleted keratinocytes were pretreated with 0,2 or $20 \mathrm{nM}$ bryostatin for 18 hours, then treated for 4 hours with the indicated concentrations of TGF- $\alpha$ and analyzed as described in Materials and Methods. Mobilities of ribosomal RNAs are indicated to the left. Data shown are representative of 3 experiments. C: Quantitation of autoradiogram shown in Fig. 6B. Analysis was performed by laser densitometry as in Fig. 4C, except that values were not normalized to cyclophilin. Cyclophilin densitometric values were within $\pm 10 \%$ in this experiment.
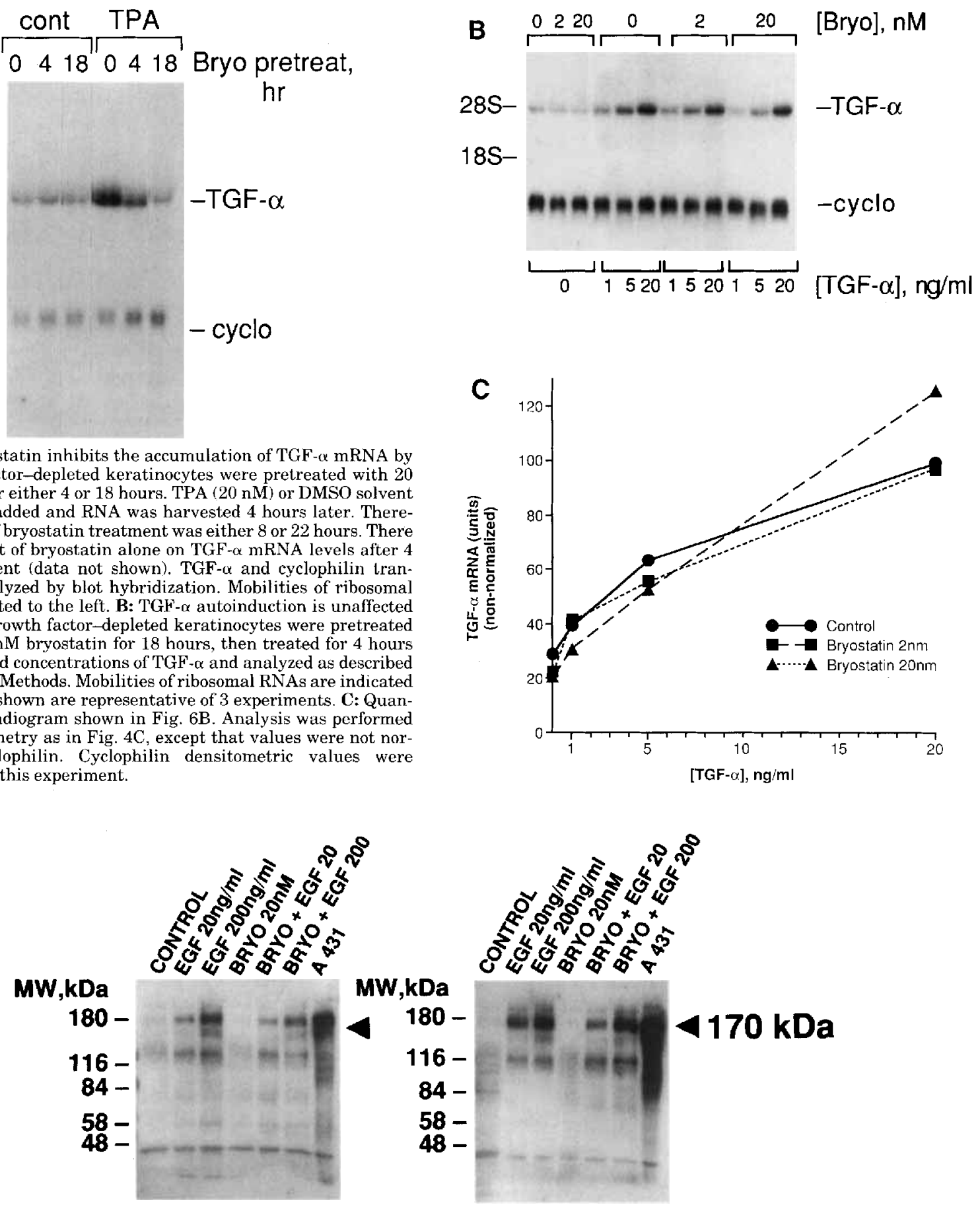

EXPERIMENT 1

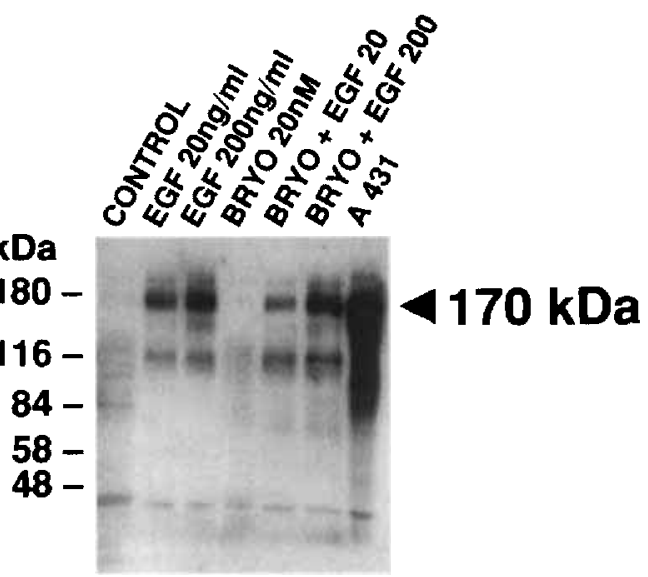

EXPERIMENT 2

Fig. 7. Immunoblot analysis of bryostatin effects on EGF-stimulated tyrosine phosphorylation in growth factor-depeleted keratinocytes. Cells were pretreated with $20 \mathrm{nM}$ bryostatin for 18 hours, then treated for 5 minutes with the indicated concentrations of EGF. The results of 2 independent experiments are shown.

\section{Summary and perspectives}

The results presented here argue for the existence of at least two pathways by which TGF- $\alpha$ can be stimulated in human keratinocytes. TGF- $\alpha$ autoinduction oc- curs via a pathway which is triggered by activation of the EGF receptor tyrosine kinase in response to EGF or TGF- $\alpha$, and is not inhibited or potentiated by bryostatin. In contrast, induction of TGF- $\alpha$ by TPA occurs inde- 
pendently of EGF receptor activation, and is inhibited by $\mathrm{PKC}$ down-regulation in response to bryostatin. It is possible that TGF- $\alpha$ plays important roles in both proliferation and differentiation of the epidermis, as suggested by Finzi et al. (1991). If this is the case, the TGF- $\alpha$ autoinductive pathway may be important in the regulation of keratinocyte growth, while the $\mathrm{PKC}$-dependent pathway of TGF- $\alpha$ activation may be involved in the regulation of keratinocyte differentiation.

\section{ACKNOWLEDGMENTS}

This work was in part supported by U.S.P.H.S. training grant 5-T32-AM07197-10 (S.B.K.), U.S.P.H.S. grants R29-AR40016 (J.T.E.) and R29-AR39691 (G.J.F.), by the Veterans Administration (J.T.E.), and by the Babcock Memorial Trust. We thank G. Petit and Rorer Biotechnology for generous gifts of bryostatin and tyrphostin RG50864, respectively, and R. Derynck, Genentech, Inc., for provision of the TGF- $\alpha$ cDNA plasmid. The skilled technical assistance of Diane Boman, Qiong Yang, Li Qin, and Kathy Leach is gratefully acknowledged.

\section{LITERATURE CITED}

Baliga, B., and Morowitz, S. (1988) Effects of growth and differentiation inducing factors on protein kinase-C of cultured intestinal crypt cells. Biochem. Biophys. Res. Commun., 154:278-284.

Barrandon, Y., and Green, H. (1987) Cell migration is essential for sustained growth of keratinocyte colonies: The roles of transforming growth factor-alpha and epidermal growth factor. Cell, 50:11311137

Bartel, R., Marcelo, C., and Voorhees, J. (1987) Partial characterization of phospholipase $\mathrm{C}$ activity in normal, psoriatic uninvolved, and lesional epidermis. J. Invest. Dermatol., 88:447-451.

Bergers, M., van de Kerkhof, P., Happle, R., and Mier, P. (1990) Membrane-bound phospholipase $\mathrm{C}$ activity in normal and psoriatic epidermis. Acta Derm. Venereol. (Stockh), 70:57-59.

Blackshear P., Witters, L., Girard, P., Duo, J., and Quamo, S. (1985) Growth factor-stimulated protein phosphorylation in 3T3-L1 cells. J. Biol. Chem., 260:13304-13315.

Blackshear, P., Haupt, D., and Stumpo, D. (1991) Insulin activation of protein kinase C: A reassessment. J. Biol. Chem., 266:10946-10952

Cartlidge, S., and Elder, J. (1989) Transforming growth factor $\alpha$ and epidermal growth factor levels in normal human gastrointestinal mucosa. Br. J. Cancer, 60:657-660.

Chen, W., Lazar, C., Poenie, M., Tsien, R., Gill, G., and Rosenfeld, M. (1987) Requirement for intrinsic protein tyrosine kinase in the immediate and late actions of the EGF receptor. Nature, 328:820-822

Chomczynski, P., and Sacchi, N. (1987) Single-step method of RNA isolation by acid guanidinium thiocyanate-phenol-chloroform extraction. Anal. Biochem., 162:156-159.

Coffey, R., Derynck, R., Wilcox, J., Bringman, T., Goustin, A., Moses, H., and Pittlekow, M. (1987) Production and auto-induction of transforming growth factor- $\alpha$ in human keratinocytes. Nature, $328: 817$ 820.

Coffey, R., Sipes, N., Bascom, C., Graves-Deal, R., Pennington, C. Weissman, B., and Moses, H. (1988) Growth modulation of mouse keratinocytes by transforming growth factors. Cancer Res., 48:1596- 1602

Davis, R. (1988) Independent mechanisms account for the regulation by protein kinase $\mathrm{C}$ of the epidermal growth factor receptor affinity and tyrosine-protein kinase activity. J. Biol. Chem., 263:9462-9469

Decker, S., Ellis, C., Pawson, T., and Velu, T. (1990) Effects of substitution of threonine 654 of the epidermal growth factor receptor on epidermal growth factor-mediated activation of phospholipase C. J. Biol. Chem., 265:7009-7015.

Derynck, R., Roberts, A., Winkler, M., Chen, E., and Goeddel, D. (1984) Human transforming growth factor- $\alpha$ : Precursor structure and expression in E. coli. Cell, $38: 287$

Dvir, A., Milner, Y., Chomsky, O. Gilon, C., Gazit, A., and Levitzki, A (1991) The inhibition of EGF-dependent proliferation of keratinocytes by tyrphostin tyrosine kinase blockers. J. Cell Biol., 113:857-865
Elder, J., Fisher, G., Lindquist, P., Bennett, G., Pittlekow, P., Coffey, Jr., E., Ellingsworth, L., Derynck, R., and Voorhees, J. (1989a) Overexpression of transforming growth factor $\alpha$ in psoriatic epidermis. Science, 243:811-814.

Elder, J., Klein, S., and Voorhees, J. (1989b) TGF- $\alpha$, a potent stimulator of keratinocyte growth, is overexpressed in psoriasis. J. Invest. Dermatol. 92:424A

Elder, J., Tavakkol, A., Klein, S., Zeigler, M., Wicha, M., and Voorhees, J. (1990) Protooncogene expression in normal and psoriatic skin. J. Invest. Dermatol., 94:19-25.

Ferriola, P., Earp, H., DiAugustine, R., and Nettesheim, P. (1991) Role of $\mathrm{TGF} \alpha$ and its receptor in proliferation of immortalized rat tracheal epithelial cells: Studies with tyrphostin and TGF $\alpha$ antisera. J. Cell. Physiol., 147:166-175.

Finzi, E., Harkins, R., and Horn, T. (1991) TGF- $\alpha$ is widely expressed in differentiated as well as hyperproliferative skin epithelium. J. Invest. Dermatol., 96:328-332.

Fisher, G., Harris, V., and Voorhees, J. (1987) Purification and characterization of calcium/phospholipid-dependent kinase from adult human epidermis. J. Invest. Dermatol., 89:484-488.

Fisher, G., Talwar, H., Baldessare, J., Henderson, P., and Voorhees, J. (1990) Increased phospholipase C-catalyzed hydrolysis of phosphatidylinositol-4,5-bisphosphate and 1,2-sn-diacylglycerol content in psoriatic involved compared to uninvolved and normal epidermis. J. Invest. Dermatol., 95:428-435.

Friedman, B., Frackelton, A., Ross, A., Connors, J., Fujiki, H., Sugimura, T., and Rosner, M. (1984) Tumor promoters block tyrosinespecific phosphorylation of the epidermal growth factor receptor. Proc. Natl. Acad. Sci. U.S.A., 81:3034-3038.

Gentleman, S., Martensen, T., Digiovanna, J., and Chader, G. (1984) Protein tyrosine kinase and protein phosphotyrosine phosphatase in normal and psoriatic skin. Biochim. Biophys. Acta 798:53-59.

Gill, G., Kawamoto, T., Cochet, C., Le, A., Sato, J., Masui, H., McLeod, C., and Mendelsohn, J. (1984) Monoclonal anti-epidermal growth factor receptor antibodies which are inhibitors of epidermal growth factor binding and antagonists of epidermal growth factor-stimulated tyrosine protein kinase activity. J. Biol. Chem., 259:77557760.

Gottlieb, A., Chang, C., Posnett, D., Fanelli, B., and Tam, J. (1988) Detection of transforming growth factor alpha in normal, malignant, and hyperproliferative human keratinocytes. J. Exp. Med., 167:670-675.

Gschwendt, M., Furstenberger, G., Rose--John, S. Rogers, M., Kittstein, W., Petit, G., Herald, C., and Marks, F. (1988) Bryostatin 1 , an activator of protein kinase $\mathrm{C}$, mimics as well as inhibits biological effects of the phorbol ester TPA in vivo and in vitro. Carcinogenesis, 9:555-562

Hanks, S., Quinn, A., and Hunter, T. (1988) The protein kinase family: Conserved features and deduced phylogeny of the catalytic domains. Science, $241: 42-52$

Hidaka, H., Inagaki, M., Kawamoto, S., and Sasaki, Y. (1984) Isoquinolinesulfonamides, novel and potent inhibitors of cyclic nucleotide dependent protein kinase $\mathrm{C}$. Biochemistry, 23:5036-5041.

Higashiyama, M., Matsumoto, K., Hashimoto, K., and Yoshikawa, K. (1991) Increased production of transforming growth factor-a in psoriatic epidermis. J. Dermatol., 18:117-119.

Honegger, A., Dull, T., Felder, S., Van Obberghen, E., Bellot, F., Szaparu, D. Schmidt, A. Ullrich, A and Schlessinger, J (1987) Point mutation of the ATP binding site of EGF receptor abolishes proteintyrosine kinase activity and alters cellular routing. Cell 51:199209 .

Honegger, A., Schmidt, A., Ullrich, A., and Schlessinger, J. (1990) Evidence for epidermal growth factor (EGF)-induced intermolecular autophosphorylation of the EGF receptors in living cells. Mol. Cell. Biol., 10:4035-4044.

Horn, F., Marks, F., Fisher, G., Marcelo, C., and Voorhees, J. (1987) Decreased protein kinase $\mathrm{C}$ activity in psoriatic versus normal epidermis. J. Invest. Dermatol. 88:220-222.

Jeng, A., Lichti, U., Strickland, J., and Blumberg, P. (1985) Similar effects of phospholipase $\mathrm{C}$ and phorbol ester tumor promoters on primary mouse epidermal cells. Cancer Res. 45:5714-5721

Jetten, A., George, M., Pettit, G., Herald, C., and Rearick, J. (1989) Action of phorbol esters, bryostatins, and retinoic acid on cholesterol sulfate synthesis: Relation to the multistep process of differentiation in human epidermal keratinocytes. J. Invest. Dermatol., 9.3:108-115.

Jhappan, C., Stahle C., Harkins R., Fausto, N., Smith, G., and Merlino, G. (1990) TGF a overexpression in transgenic mice induces liver neoplasia and abnormal development of the mammary gland and pancreas. Cell, 61:1137-1146. 
Johnson, R., and Garrison, J. (1987) Epidermal growth factor and angiotensin II stimulate formation of inositol 1,4,5- and inositol 1,3,4-trisphosphate in hepatocytes. J. Biol. Chem., 262:1728517293.

Kato, M., Takenawa, T., and Twardzik, D. (1988) Effect of transforming growth factor- $\alpha$ on inositol phospholipid metabolism in human epidermold carcinoma cells. J. Cell. Biochem., 37:339-345.

Kawamoto, T., Sato, J.D., Le, A., Polikoff, J., Sato, G.H., and Mendelsohn, J. (1983) Growth stimulation of A431 cells by EGF: Identification of high affinity receptors for epidermal growth factor by an anti-receptor monoclonal antibody. Proc. Natl. Acad. Sci. U.S.A., 80:1337-1341.

Kikkawa, U., Takai, Y., Minakuchi, R., Inohara, S., and Nishizuka, Y. (1982) Calcium-activated, phospholipid-dependent protein kinase from rat brain. J. Biol. Chem., 257:13342-13348.

Koch, C., Anderson, A., Moran, M., Ellis, C., and Pawson, T. (1991) SH2 and SH3 domains: Elements that control interactions of cytoplasmic signaling proteins. Science, 252:668-674.

Koyama, S., and Podolsky, D. (1989) Differential expression of transforming growth factors $\alpha$ and $\beta$ in rat intestinal epithelial cells. J. Clin. Invest., 83:1768-1773.

Kraft, A., Barker, V., and May, W. (1987) Bryostatin induces changes in protein kinase $\mathrm{C}$ location and activity without altering c-myc gene expression in human promyelocytic leukemia cells (HI,-60). Oncogene, 1:111-118.

Livneh, E., Dull, T., Berent, E., Prywes, R., Ullrich, A., and Schlessinger, J. (1988) Release of a phorbol ester-induced mitogenic block by mutation at Thr-654 of the epidermal growth factor receptor. Mol. Cell. Biol., 8:2302-2308.

Lyall, R., Zilberstein, A., Gazit, A., Gilon, C., Levitzki, A., and Schlessinger, J. (1989) Tyrphostins inhibit epidermal growth factor (EGF)receptor tyrosine kinase activity in living cells and EGF-stimulated cell proliferation. J. Biol. Chem., 264:14503-14509.

Malden, L., Novak, U., and Burgess, A. (1989) Expression of transforming growth factor alpha messenger RNA in the normal and neoplastic gastro-intestinal tract. Int. J. Cancer, 43:380-384.

Margolis, B., Rhee, S., Felder, S., Mervic, M., Lyall, R., Levitzki, A. Ullrich, A., Zilberstein A., and Schlessinger, J. (1989) EGF induces tyrosine phosphorylation of phospholipase C-II: A potential mechanism for EGF receptor signalling. Cell, 57:1101-1107.

Markowitz, S., Molkentin, K., Gerbic, C., Jackson, J., Stellato, T., and Willson, J. (1990) Growth stimulation by coexpression of transforming growth factor- $\alpha$ and epidermal growth factor receptor in normal and adenomatous human colon epithelium. J. Clin. Invest., 86:356362 .

Massague, J. (1983) Type beta transforming growth factor from feline sarcoma virus-transformed rat cells. Isolation and biological properties. J. Biol. Chem., 258:13614.

Matsui, Y., Halter, S., Holt, J., Hogan B., and Coffey, R. (1990) Development of mammary hyperplasia and neoplasia in MMTV-TGF $\alpha$ transgenic mice. Cell, 61:1147-1155.

Mead, J., and Fausto, N. (1989) Transforming growth factor $\alpha$ may be a physiological regulator of liver regeneration by means of an autocrine mechanism. Proc. Natl. Acad. Sci. U.S.A., 86:1558-1562

Moscat, J., Molloy, C., Fleming, T., and Aaronson, S. (1988) Epidermal growth factor activates phosphoinositidue turnover and protein $\mathrm{ki}$ nase-C in BALB/MK keratinocytes. Mol. Endocrinol., 2:799-805.

Nickoloff, B., and Mitra, R. (1989) Inhibition of ${ }^{125}$ I-epidermal growth factor binding to cultured keratinocytes by antiproliferative molecules gamma interferon, cyclosporin $\mathrm{A}$, and transforming growth factor-beta. I. Invest. Dermatol., 93:799 803.

Nickoloff, B., Mitra, R., Elder, J., Fisher, G., and Voorhees, J. (1989) Decreased growth inhibition by recombinant gamma interferon is associated with increased transforming growth factor- $\alpha$ production in keratinocytes cultured from psoriatic lesions. Br. J. Dermatol., 111:161-174.

Nishibe, S., Wabl, M., Wedegaertner, P., Kim, J., Rhee, S., and Carpenter, S. (1990) Selectivity of phospholipase C phosphorylation by the epidermal growth factor receptor, the insulin receptor, and their cytoplasmic domains. Proc. Natl. Acad. Sci. U.S.A., 87:424-428.

Pessin, M., Baldessare, J., and Raben, D. (1990) Molecular species analysis of mitogen-stimulated 1,2-diglycerides in fibroblasts. $J$. Biol. Chem., 265:7959-7966.

Pierce, J., Ruggiero, M., Fleming, T., Di Fiore, P., Greenberger, J., Vartincovski, L., Schlessinger, J., Rovera, G., and Aaronson, S. (1988) Signal transduction through the EGF receptor transfected in IL-3-dependent hematopoietic cells. Science, 239:628-631.

Pittelkow, M., Lindquist, P., Abraham, R., Graves-Deal, R., Derynck, R., and Coffey, R. (1989) Induction of transforming growth factor-a expression in human keratinocytes by phorbol esters. J. Biol. Chem., 264:5164-5171.

Posner, I., Gazit, A., Gilon, C., and Levitzki, A. (1989) Tyrphostins inhibit the epidermal growth factor receptor-mediated breakdown of phosphoinositides. FEBS Lett., 257:287-291.

Sako, T., Yuspa, S., Herald, C. Pettit, G, and Blumberg, P. (1987) Partial parallelism and partial blockage by bryostatin 1 of effects of phorbol ester tumor promoters on primary mouse epidermal cells. Cancer Res., 47:5445-5450.

Sandgren, E., Luetteke, N., Palmiter, R., Brinster, R., and Lee, D. (1990) Overexposure of TGF $\alpha$ in transgenic mice: Induction of epithelial hyperplasmia, pancreatic metaplasia, and carcinoma of the breast. Cell, 61:1121-1135.

Smith, J., Smith, L., and Petit, G. (1985) Bryostatins: Potent, new mitogens that mimic phorbol esters. Biochem. Biophys. Res. Commun., 132:939-945.

Sunada, H., Magun, B., Mendelsohn, J., and MacLeod, C. (1986) Monoclonal antibody against epidermal growth factor receptor is internalized without stimulating receptor phosphorylation. Proc. Nat1 Acad. Sci. U.S.A. 83:3825-3829.

Sunada, H., Yu, P., Peacock, J., and Mendelsohn, J. (1990) Modulation of tyrosine, serine, and threonine phosphorylation and intracellular processing of the epidermal growth factor receptor by antireceptor monoclonal antibody. J. Cell. Physiol., 142:284-292.

Tapley, ., and Murray, A. (1984) Evidence that treatment of platelets with phorbol ester causes proteolytic activation of $\mathrm{Ca} 2+$-activated, phospholipid-dependent protein kinase. Eur. J. Biochem., 151:419423.

Thompson, D., Proctor, J., Grant, M., and Thomas, C. (1988) Epidermal growth factor stimulates phosphatidylinositol turnover for ten hours in A431 cells without activation of protein kinase C. Biochem. Biophys. Res. Commun., 155:877-881.

Tsao, M., Walthall, B., and Ham, R. (1982) Clonal growth of normal human epidermal keratinocytes in a defined medium. J. Cell. Physiol., 110:219-229.

Vaartjes, W., de Haas, C., and van den Bergh, S. (1986) Phorbol esters, but not epidermal growth factor or insulin, rapidly decrease soluble protein kinase $\mathrm{C}$ activity in rat hepatocytes. Biochem. Biophys. Res. Commun., 138:1328-1333

Vassar, R., and Fuchs, E. (1991) Transgenic mice provide new insight in to the role of TGF- $\alpha$ during epidermal development and differentiation. Genes Dev., 5:714-727.

Wahl, M., Daniel, T., and Carpenter, G. (1988) Antiphosphotyrosine recovery of phospholipase $C$ activity after EGF treatment of A-431 cells. Science, 241:968-970.

Wille, J., Pittelkow, M., Shipley, G., and Scott, R. (1984) Integrated control of growth and differentiation of normal human prokeratinocytes cultured in serum-free medium: Clonal analyses, growth kinetics, and cell cycle studies. J. Cell. Physiol., 121:31-44. 